\title{
Genetic Parameters and Trends in the Chilean Multibreed Dairy Cattle Population*
}

\author{
M. A. Elzo, ${ }^{1}$ A. Jara, ${ }^{2}$ and N. Barria ${ }^{2}$ \\ ${ }^{1}$ University of Florida, Gainesville 32611 \\ ${ }^{2}$ University of Chile, Santiago, Chile
}

\begin{abstract}
Estimates of additive and nonadditive multibreed covariance components, genetic parameters, and predicted genetic values for first lactation 305-d mature equivalent (ME) milk yield, fat yield, and protein yield were computed using data from a sample of 3316 cows from the Chilean Holstein-other breeds multibreed population. Variances and covariances were estimated by 2-trait REML analyses using a Generalized Expectation-Maximization algorithm applied to multibreed populations. Multiple estimates of additive genetic, nonadditive genetic, and environmental variances from 2 -trait analyses were averaged to yield a single variance estimate for each trait and effect. Heritabilities were moderate for all traits in Holstein, other, and Holstein $\times$ other crossbred groups. Interbreed interactibilities (ratio of nonadditive genetic to phenotypic variances) were all near zero. Multibreed additive, nonadditive, and total genetic trends were estimated using the complete dataset $(56,277$ cows). Upward trends between 1990 and 2000 existed for all traits, genetic effects, and breed groups, except for 305-d ME protein yield in $1 / 4$ Holstein, indicating that Chilean dairy producers were successful in choosing progressively better semen and sires from imported and local sources over time.
\end{abstract}

(Key words: genetic parameter, genetic trend, multibreed, upgrading)

Abbreviation key: $\mathbf{H}=$ Holstein, $\mathbf{H} / \mathbf{O}=$ intralocus Holstein/other breeds, FY $=305$-d mature equivalent fat yield, $\mathbf{M E}=$ mature equivalent, $\mathbf{M P T A}=$ multibreed PTA, MREMLEM = multibreed REML using a generalized expectation-maximization algorithm, $\mathbf{M Y}=305-\mathrm{d}$ mature equivalent milk yield, $\mathbf{O}=$ other breeds, $\mathbf{P Y}=$ 305-d mature equivalent protein yield.

Received August 25, 2003.

Accepted December 20, 2003.

Corresponding author: M. A. Elzo; e-mail: elzo@animal.ufl.edu.

*This research was supported by the Florida Agricultural Experiment Station and grants from the National Fund for Science and Technology of Chile (Projects No. 1000792 and 7000792) and was approved for publication as Journal Series No. R-09693.

\section{INTRODUCTION}

Milk production in the 9 th and 10th regions in Southern Chile accounts for approximately $75 \%$ of the total produced in the country (ODEPA, 2003). In the mid 1970s, dairy producers in these regions began to import Holstein semen from various countries with the purpose of rapidly increasing milk yield by incorporating Holstein (H) germplasm into the local dual-purpose Black and White European Friesian cattle population. Most $\mathrm{H}$ semen came from the US and Canada. Chilean cattle producers made a concerted effort to upgrade the original cattle population to $\mathrm{H}$ imported directly from the US more than from any other country (Barría et al., 2001). Conversely, before the surge in importation of $\mathrm{H}$ semen, cattlemen in these regions had been importing European Friesian germplasm primarily from Germany and The Netherlands. The result of these 2 periods of semen importation was the creation of a complex multibreed population with more than 10 breed $\times$ country combinations.

Intrabreed analyses of this multibreed population have shown that European Friesian cows had lower milk production than straightbred and crossbred $\mathrm{H}$, provided that the management and nutritional demands of these animals were met (Barría and Stolzenbach, 1992; Barría et al., 1995, 2001). Barría et al. (1995) also found positive genetic trends for milk and fat yields for animals born between 1981 and 1988 for the complete multibreed dataset. However, these intrabreed analyses provided an incomplete picture of the impact of the $\mathrm{H}$ semen importation on milk production traits in the various breed groups present in the Chilean dairy population in terms of their genetic variability and individual genetic trends. Further, largely because of economic reasons, breeding goals differed widely across herds. Thus, there was ample variation in the breed composition of animals throughout the dairy population in Regions 9 and 10 of Southern Chile. Consequently, to obtain a more complete understanding of the impact of the incorporation of $\mathrm{H}$ genetic material into the Chilean Friesian population, a multibreed analysis of this population was needed.

Because many breed group subclasses had numbers of animals and records that were too small to be treated 
as separate categories, only 2 base populations formed by groups of breed $\times$ country subclasses were considered here: North American H and other breeds (O). Holstein encompassed genetic material imported from the US and Canada, and $\mathrm{O}$ included all Chilean Friesian, imported European Friesian (Germany, The Netherlands), and Friesian genetic material imported from England and New Zealand.

The objectives of this research were to estimate genetic and environmental variations in $\mathrm{H}, \mathrm{O}$, and various $\mathrm{H} \times \mathrm{O}$ subclasses, and to examine genetic trends that occurred between 1990 and 2000 in the various breed groups of the Chilean multibreed dairy population using 305-d ME first lactation records.

\section{MATERIAL AND METHODS}

\section{Climate, Management, and Nutrition}

The climate in the 9th and 10th regions of Southern Chile (39 to $42^{\circ}$ latitude South) is temperate, with moderate temperatures (usually between 5 and $25^{\circ} \mathrm{C}$ ) and 1300 to $2500 \mathrm{~mm}$ of rain throughout the year (Teuber, 1996). Cows were primarily kept outdoors throughout the year, except in winter (late May to early August), when they were moved indoors at night for protection from the cold and strong rainfall typical of the season. Feeding was based mainly on rotational grazing in improved pastures, grass hay and silage, corn silage, alfalfa (Medicago sativa) greenchop, and concentrate. Improved pastures were normally a mixture of roughly $70 \%$ grammineous grasses and $30 \%$ leguminous grasses (Teuber, 1996). Some of the most frequently used grass mixtures were ryegrass (Lolium perenne) and white clover (Trifolium repens) and tall fescue (Festuca arundinacea) and white clover.

\section{Dataset}

The information contained in the Chilean dairy dataset came from the official dairy recording program and was collected by COOPRINSEM ${ }^{\circledR}$ in the 9 th and 10 th regions of Southern Chile between 1990 and 2000. Only herds milked twice a day were considered. Raw data were edited for erroneous information. An in-house computer program using a linked-list algorithm was used to check for the presence of common sires across herd-year seasons and to put records from all cows in these linked herd-year seasons into connected sets. Only the largest connected set was used here. Records were adjusted to 305-d mature equivalents (ME) using multiplicative correction factors obtained in an earlier study by 2 of the authors (N. Barria and A. Jara, 2000, unpublished report) with a subset of the data $(40,186$ cows born between 1992 and 1999). The resulting com- plete connected multibreed Chilean dataset consisted of 56,277 first lactation 305-d ME milk yield (MY), 56,277 fat yield (FY), and 31,160 protein yield (PY) records. Five breed groups of sires and dams were defined: $\mathrm{H}, 3 / 4 \mathrm{H} 1 / 4 \mathrm{O}, 1 / 2 \mathrm{H} 1 / 2 \mathrm{O}, 1 / 4 \mathrm{H} 3 / 4 \mathrm{O}$, and $\mathrm{O}$. Cows were the progeny of 1202 straightbred and crossbred sires and 34,672 straightbred and crossbred dams.

\section{Model}

A multiple-trait, multibreed, sire-maternal grandsire model was used to estimate covariances and to predict genetic values. Fixed environmental effects were herdyear seasons. Fixed regression genetic group effects were 1) sire-maternal grandsire intrabreed $\mathrm{H}$ additive direct (deviated from $\mathrm{O}$ ) as a function of the $\mathrm{H}$ fraction in the sire plus 0.5 times the $\mathrm{H}$ fraction in the maternal grandsire, 2) sire $\mathbf{H} / \mathbf{O}$ (intralocus $\mathrm{H} / \mathrm{O}$ ) nonadditive direct (deviated from intralocus $\mathrm{H} / \mathrm{H}$ and intralocus $\mathrm{O} / \mathrm{O}$ ) as a function of the probability of $\mathrm{H}$ and $\mathrm{O}$ alleles at one locus in the daughters of all sires, and 3) maternal granddam intrabreed $\mathrm{H}$ additive direct (deviated from $\mathrm{O}$ ) as a function of the $\mathrm{H}$ fraction in maternal granddams. Random effects were 1) sire additive direct, 2) maternal grandsire additive direct, 3 ) regression of sire $\mathrm{H} / \mathrm{O}$ nonadditive direct (as a function of the probabilities of $\mathrm{H}$ and $\mathrm{O}$ alleles in the daughters of a particular sire), and 4) residual. The multibreed model in matrix form was

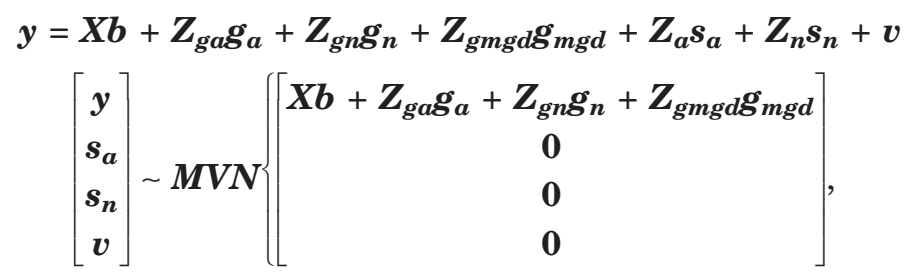

$$
\left.\left[\begin{array}{cccc}
Z_{a} G_{a} Z_{a}^{\prime}+Z_{n} G_{n} Z_{n}^{\prime}+R & Z_{a} G_{a} & Z_{n} G_{n} & R \\
G_{a} Z_{a}^{\prime} & G_{a} & 0 & 0 \\
G_{n} Z_{n}^{\prime} & 0 & G_{n} & 0 \\
R & 0 & 0 & R
\end{array}\right]\right\}
$$

where

$\mathbf{y}=$ vector of cow records for $\mathrm{MY}, \mathrm{FY}$, and PY ordered by traits within cows;

$\mathbf{b}=$ vector of herd-year seasons;

$\mathbf{g}_{\mathbf{a}}=$ vector of sire-maternal grandsire intrabreed $\mathrm{H}$ additive direct genetic group effects;

$\mathbf{g}_{\mathbf{n}}=$ vector of sire $\mathrm{H} / \mathrm{O}$ nonadditive direct genetic group effects; 
$\mathbf{g}_{\mathbf{m g d}}=$ vector of maternal granddam intrabreed $\mathrm{H}$ additive direct genetic group effects;

$\mathbf{s}_{\mathbf{a}}=$ vector of sire and maternal grandsire additive direct genetic effects;

$\mathbf{s}_{\mathbf{n}}=$ vector of sire $\mathrm{H} / \mathrm{O}$ nonadditive direct genetic effects;

$\mathbf{v}=$ vector of residuals;

$\mathbf{X}=$ matrix that relates cow records to elements of $\mathrm{b}$ ( $1 \mathrm{~s}$ and $0 \mathrm{~s})$;

$\mathbf{Z}_{\text {ga }}=$ matrix that relates cow records to elements of $\mathbf{g}_{\mathbf{a}}$ through the expected fraction of $\mathrm{H}$ alleles in the sire and the maternal grandsire of a cow $\left(\mathrm{p}_{\mathrm{Hs}}+0.5 \mathrm{p}_{\mathrm{Hm}}\right)$, where $\mathrm{p}=$ probability and the subscripts $\mathrm{s}=$ sire and $\mathrm{m}=$ maternal grandsire;

$\mathbf{Z}_{\mathbf{g n}}=$ matrix that relates cow records to elements of $\mathbf{g}_{\mathbf{n}}$ through the probability of intralocus $\mathrm{H}$ and $\mathrm{O}$ alleles in the cow $\left(\mathrm{p}_{\mathrm{Hs}} \mathrm{p}_{\mathrm{Od}}+\mathrm{p}_{\mathrm{Os}} \mathrm{p}_{\mathrm{Hd}}\right)$, where the subscript $d=$ dam;

$\mathbf{Z}_{\text {gmgd }}=$ matrix that relates cow records to elements of $\mathbf{g}_{\mathbf{m g d}}$ through the expected fraction of $\mathrm{H}$ alleles in the maternal granddam;

$\mathbf{Z}_{\mathbf{a}}=$ matrix that relates cow records to elements of $\mathbf{s}_{\mathbf{a}}$ through the sire (1) and the maternal grandsire (0.5);

$\mathbf{Z}_{\mathbf{n}}=$ matrix that relates cow records to elements of $\mathbf{s}_{\mathbf{n}}$ through the probability of intralocus $\mathrm{H}$ and $\mathrm{O}$ alleles in the cow $\left(\mathrm{p}_{\mathrm{Hs}} \mathrm{p}_{\mathrm{Od}}+\mathrm{p}_{\mathrm{Os}} \mathrm{p}_{\mathrm{Hd}}\right)$;

MVN = multivariate normal,

$\mathbf{G}_{\mathrm{a}}=$ matrix of multibreed additive genetic variances of and covariances between elements of $\mathbf{s}_{\mathbf{a}}$;

$\mathbf{G}_{\mathbf{n}}=$ matrix of multibreed nonadditive genetic variances of and covariances between elements of $\mathbf{s}_{\mathbf{n}}$; and

$\mathbf{R}=$ matrix of multibreed residual variances of and covariances between elements of $\mathbf{v}$.

Preliminary versions of this model assumed that heterogeneity of multibreed additive genetic covariances across breed groups was due to intrabreed and interbreed additive genetic covariances. However, initial estimates of covariance components consistently yielded values of interbreed additive genetic covariances near zero; thus, they were assumed to be zero in subsequent versions of this model. Covariances among sire and maternal grandsire additive genetic effects and covariances among sire H/O nonadditive genetic effects were accounted for.

\section{Computing Strategy}

The multibreed mixed model equations were constructed and solved using a strategy similar to one previously used for beef (Elzo and Wakeman, 1998; Elzo et al., 1998a,b) and dairy (Koonawootrittriron et al.,
$2002)$ traits. The inverse of the multibreed additive covariance matrix $\mathbf{G}_{\mathbf{a}}$ was computed using the recursive algorithm described in Elzo (1990a), and the inversion of the nonadditive covariance matrix $\mathbf{G}_{\mathbf{n}}$ used rules for regression of nonadditive effects at one locus (Elzo, $1990 \mathrm{~b})$. The multibreed mixed model equations were half-stored in sparse form and solved using FSPAK (Perez-Enciso et al., 1994) to obtain additive and nonadditive genetic predictions. Subsequently, residual additive genetic and nonadditive genetic predictions (Elzo and Wakeman, 1998) and predictions of residuals from the multibreed model plus their corresponding error variances of prediction were used to compute multibreed covariances. The 2003 version of program MREMLEM (multibreed REML using a generalized expectation-maximization algorithm) (Elzo, 1994, 1996) was used to perform computations.

\section{Estimation of Covariance Components}

Covariance components were obtained using REML procedures (Harville, 1977) applied to multibreed populations (Elzo, 1994, 1996). This is a 3-step procedure. First, the Cholesky elements of the $\mathrm{H}$ and $\mathrm{O}$ additive genetic and environmental covariances and $\mathrm{H} / \mathrm{O}$ nonadditive genetic covariances were computed using a generalized expectation-maximization algorithm (Dempster et al., 1977). This step was built into the algorithm of MREMLEM to ensure positive definiteness of the estimated covariance matrices. Second, the $\mathrm{H}$ and $\mathrm{O}$ additive genetic and environmental and $\mathrm{H} / \mathrm{O}$ nonadditive genetic covariance matrices were computed by multiplying the appropriate Cholesky matrices by their transposes. Third, additive covariance matrices for progeny from various breed group of sire $\times$ breed group of dam combinations were computed by adding the product of the $\mathrm{H}$ and $\mathrm{O}$ fractions in the progeny times their corresponding covariance matrices.

Convergence failure with the complete dataset forced the use of a subset of the Chilean multibreed dataset for the estimation of covariance components. This subset permitted the estimation of covariance components for, at most, 2 traits simultaneously. Thus, three 2 -trait runs were made 1) MY and FY, 2) MY and PY, and 3) FY and PY. Multiple estimates of variances were averaged to yield a single estimate. To preserve positive definiteness, if a covariance was larger than the product of the mean standard deviations of 2 traits, it was replaced by this product times 0.99 . Starting values for variances in the 2-trait MREMLEM analyses were the additive and nonadditive genetic and environmental variances estimated in preliminary single-trait MREMLEM analyses and zeroes for all covariances. Convergence was assumed when the ratio of the sum of squares 
of the differences between estimates of covariances in iterations $i$ and $i+1$ to the sum of squares of covariance estimates in iteration $i$ was $<10^{-4}$. Expectation-maximization algorithms do not compute the information matrix; thus, standard errors of estimates of Cholesky elements were not computed by the MREMLEM program. However, because of the small size of the subset used to estimate multibreed covariance components, their standard errors are expected to be large.

\section{Genetic Parameters}

Linear combinations of estimates of intrabreed additive genetic, interbreed nonadditive genetic, and intrabreed environmental covariance components were used to compute multibreed additive genetic, nonadditive genetic, environmental, and phenotypic covariances (Elzo and Wakeman, 1998; Elzo et al., 1998a,b). Subsequently, ratios of additive genetic to phenotypic variances (heritabilities), nonadditive genetic to phenotypic variances (interactibilities), and correlations (additive genetic, nonadditive genetic, environmental, phenotypic) were computed for all parental breed group combinations.

\section{Genetic Trends}

A 3-trait analysis, MY, FY, and PY, was performed to obtain additive, nonadditive, and total multibreed PTA (MPTA) for all sires and maternal grandsires in the complete Chilean dataset. Additive, nonadditive, and environmental variances and covariances were those obtained in the 2-trait variance component estimation analyses. Variances used were means of estimates from the 2-trait variance component analyses. Sire additive MPTA were obtained directly from the mixed model equations. Sire nonadditive MPTA were computed as the product of the probability of $\mathrm{H} / \mathrm{O}$ interactions in the progeny of sires mated to $\mathrm{F} 1$ dams times the base interbreed nonadditive MPTA of each sire. Mating to F1 dams was chosen because progeny from sires of all breed groups have the same intralocus interbreed probability (0.5); thus, sires can be compared on an equal basis (Elzo and Wakeman, 1998). Sire total MPTA were computed by adding each sire's additive and nonadditive MPTA.

Additive, nonadditive, and total MPTA were used to compute weighted sire plus maternal grandsire MPTA yearly means, unweighted sire MPTA yearly means, and unweighted maternal grandsire MPTA yearly means. The combined sire plus maternal grandsire yearly means could be viewed as an approximation to cow yearly means. Weights were number of daughters per year for sires and 0.5 times number of granddaugh- ters per year for maternal grandsires. Standard errors of prediction of yearly means were computed using the expression:

$$
\text { SEP yearly mean }=\left\{\left[\sum_{i}\left(\boldsymbol{n}_{i}\right)^{2} \boldsymbol{E V} \boldsymbol{P}_{i}\right] /\left[\sum_{i} \boldsymbol{n}_{i}\right]^{2}\right\}^{1 / 2}
$$

where

$n_{i}=$ number of progeny of sire $\mathrm{i}$, or 0.5 times number of grandprogeny of maternal grandsire i, for weighted sire plus maternal grandsire means, and one for unweighted means and

$E V P_{i}=$ error variance of prediction for sire i, or for maternal grandsire $i$, taken from the diagonal element of the inverse of the left-hand side of the mixed model equations and computed using FSPAK (Perez-Enciso et al., 1994).

To obtain information on the change in the yearly mean genetic value of $\mathrm{H}$ and $\mathrm{O}$ in the complete multibreed population, regression yearly means were computed using an ordinary least squares approach, where the incidence matrix was composed of $\mathrm{H}$ fractions, $\mathrm{O}$ fractions, and zeroes. The resulting $\mathrm{H}$ and $\mathrm{O}$ regression means accounted for changes coming from all $\mathrm{H}$ and $\mathrm{O}$ alleles in the Chilean multibreed population. Differences between $\mathrm{H}$ and $\mathrm{O}$ regression and subclass means would be due to the effects of genes coming from crossbred animals.

\section{RESULTS AND DISCUSSION}

\section{Dataset}

Table 1 shows the distribution of sires, dams, and cows with records by breed group of sire $\times$ breed group of dam combination. Numbers in Table 1 suggest that, because of the upgrading process, there was a substantially larger representation of $\mathrm{H}$ (and high percentage $\mathrm{H})$ than $\mathrm{O}$ sires during the $11 \mathrm{yr}$ covered in this study. However, sires in the O group continued to be steadily used by a segment of the Chilean dairy population, which indicated that some Chilean dairy producers preferred crossbred animals to straightbred $\mathrm{H}$ and that the favored $\mathrm{H}$ fraction varied across cattle farms.

Table 2 presents a description of the complete dataset in terms of means and standard deviations by breed group of sire $\times$ breed group of dam combination. All cows in Table 1 had records of MY and FY. However, because protein recording in Regions 9 and 10 of Southern Chile began in 1995, only 31,160 of them had PY records.

The mean of straightbred $\mathrm{H}$ cows for MY was approximately $2200 \mathrm{~kg}$ larger than that of cows in the O group, 
Table 1. Numbers of sires, dams, and cows in the complete Chilean multibreed population by breed group of sire $\times$ breed group of dam combination.

\begin{tabular}{|c|c|c|c|c|c|c|}
\hline \multirow{2}{*}{$\begin{array}{l}\text { Breed group } \\
\text { of dam }\end{array}$} & \multicolumn{6}{|c|}{ Breed group of sire ${ }^{1}$} \\
\hline & $\mathrm{H}$ & $3 / 4 \mathrm{H} 1 / 4 \mathrm{O}$ & $1 / 2 \mathrm{H} 1 / 2 \mathrm{O}$ & $1 / 4 \mathrm{H} \mathrm{3/4} \mathrm{O}$ & $\mathrm{O}$ & All \\
\hline \multicolumn{7}{|l|}{$\mathrm{H}$} \\
\hline Sires, no. & 182 & 10 & 19 & 2 & 50 & 263 \\
\hline Dams, no. & 734 & 36 & 41 & 2 & 81 & 871 \\
\hline Cows, no. & 913 & 36 & 42 & 2 & 86 & 1079 \\
\hline \multicolumn{7}{|l|}{$3 / 4 \mathrm{H}^{1 / 4} \mathrm{O}$} \\
\hline Sires, no. & 387 & 30 & 49 & 8 & 119 & 593 \\
\hline Dams, no. & 4091 & 238 & 324 & 27 & 405 & 4726 \\
\hline Cows, no. & 5154 & 248 & 336 & 27 & 443 & 6208 \\
\hline \multicolumn{7}{|l|}{$1 / 2 \mathrm{H} 1 / 2 \mathrm{O}$} \\
\hline Sires, no. & 513 & 37 & 87 & 15 & 215 & 867 \\
\hline Dams, no. & 8388 & 691 & 1002 & 107 & 1079 & 10,230 \\
\hline Cows, no. & 11,940 & 752 & 1113 & 109 & 1245 & 15,159 \\
\hline \multicolumn{7}{|l|}{$1 / 4 \mathrm{H} \mathrm{3/4} \mathrm{O}$} \\
\hline Sires, no. & 431 & 36 & 91 & 13 & 212 & 783 \\
\hline Dams, no. & 3932 & 374 & 886 & 119 & 1020 & 5471 \\
\hline Cows, no. & 5319 & 393 & 951 & 120 & 1166 & 7949 \\
\hline \multicolumn{7}{|l|}{ Other } \\
\hline Sires, no. & 509 & 45 & 108 & 20 & 329 & 1011 \\
\hline Dams, no. & 8488 & 995 & 1992 & 280 & 3492 & 13,374 \\
\hline Cows, no. & 15,481 & 1480 & 3246 & 327 & 5348 & 25,882 \\
\hline \multicolumn{7}{|l|}{ All } \\
\hline Sires, no. & 597 & 50 & 124 & 22 & 409 & 1202 \\
\hline Dams, no. & 25,693 & 2334 & 4245 & 535 & 6077 & 34,672 \\
\hline Cows, no. & 38,807 & 2909 & 5688 & 585 & 8288 & 56,277 \\
\hline
\end{tabular}

${ }^{1} \mathrm{H}=$ Holstein; $\mathrm{O}=$ other breeds.

reaffirming the advantage of $\mathrm{H}$ over other dairy breeds. Further, the mean of H-sired cows was roughly 1400 $\mathrm{kg}$ larger than that of O-sired cows. On the dam side, crossbred cows whose $\mathrm{H}$ fraction was $1 / 2$ and higher performed not very differently from straightbred $\mathrm{H}$ cows.

\section{Estimates of Variance and Covariance Components}

Base variance and covariance components. Base additive genetic variances and covariances explain the additive genetic variation and covariation that exist within and between traits because of alleles from $\mathrm{H}$ and $\mathrm{O}$ origins. Similarly, base environmental variances and covariances explain the environmental variation and covariation that can be attributed to animals with $\mathrm{H}$ and $\mathrm{O}$ alleles. Base nonadditive interbreed genetic variances and covariances account for interactions between $\mathrm{H}$ and $\mathrm{O}$ alleles at one locus in crossbred animals. In a multibreed sire-maternal grandsire model, base additive and interbreed nonadditive variances and covariances are estimated within sire subclasses, i.e., they use information from all straightbred and crossbred progeny of a sire or a maternal grandsire. Base environmental variances and covariances are estimated using residual information from all cows. Base phenotypic variances and covariances are computed by adding the corresponding $\mathrm{H}$ and $\mathrm{O}$ additive and environmental variance and covariance estimates.

Preliminary computer runs using the complete dataset to estimate multibreed covariance components failed to achieve convergence. This might have been due to small size and poor representation of sires and breed groups of dams in most herd-year season subclasses. Thus, for the estimation of covariance components and genetic parameters, a subset of the complete dataset was constructed by imposing the following restrictions: 1) a minimum of 40 progeny per sire, 2) 6 or more herd-year seasons per sire, 3 ) sires with progeny from all 5 breed groups of dams, and 4) at least 4 sire breed groups per herd-year season. The resulting subset contained 3316 cows, the product of 149 sires and 2775 dams (Table 3).

Estimates of base $\mathrm{H}$ and $\mathrm{O}$ additive genetic and environmental and $\mathrm{H} / \mathrm{O}$ nonadditive genetic variances and covariances among traits computed using the subset of the Chilean multibreed dairy population are shown in Table 4. Variances in Table 4 are means of pairs of estimates from three 2-trait MREMLEM computer runs (MY and FY, MY and PY, and FY and PY).

Intrabreed additive genetic, environmental, and phenotypic variances and covariances were somewhat larger in $\mathrm{H}$ than in $\mathrm{O}$ for all traits, suggesting that the climatic, nutritional, and management conditions in 
Table 2. Means and standard deviations (kg) for 305-d mature equivalent milk yield (MY), fat yield (FY), and protein yield (PY) in the complete Chilean multibreed population by breed group of sire $\times$ breed group of dam combination.

\begin{tabular}{|c|c|c|c|c|c|c|}
\hline \multirow{2}{*}{$\begin{array}{l}\text { Breed group } \\
\text { of dam }\end{array}$} & \multicolumn{6}{|c|}{ Breed group of sire ${ }^{1}$} \\
\hline & $\mathrm{H}$ & $3 / 4 \mathrm{H} 1 / 4 \mathrm{O}$ & $1 / 2 \mathrm{H} 1 / 2 \mathrm{O}$ & $1 / 4 \mathrm{H} \mathrm{3/4} \mathrm{O}$ & $\mathrm{O}$ & All \\
\hline \multicolumn{7}{|l|}{$\mathrm{H}$} \\
\hline MY & $7981 \pm 1586$ & $7886 \pm 1419$ & $7756 \pm 1576$ & $8259 \pm 655$ & $7688 \pm 1372$ & $7946 \pm 1563$ \\
\hline FY & $296 \pm 61$ & $289 \pm 53$ & $291 \pm 61$ & $306 \pm 67$ & $285 \pm 58$ & $295 \pm 61$ \\
\hline PY & $253 \pm 53$ & $247 \pm 45$ & $243 \pm 57$ & $279 \pm 0^{2}$ & $244 \pm 47$ & $252 \pm 52$ \\
\hline \multicolumn{7}{|l|}{$3 / 4 \mathrm{H} 1 / 4 \mathrm{O}$} \\
\hline MY & $7822 \pm 1711$ & $7573 \pm 1523$ & $7697 \pm 1553$ & $8307 \pm 1090$ & $7305 \pm 1532$ & $7771 \pm 1687$ \\
\hline FY & $288 \pm 60$ & $281 \pm 53$ & $288 \pm 60$ & $303 \pm 51$ & $276 \pm 57$ & $287 \pm 59$ \\
\hline PY & $246 \pm 54$ & $235 \pm 47$ & $248 \pm 48$ & $254 \pm 29$ & $236 \pm 53$ & $245 \pm 54$ \\
\hline \multicolumn{7}{|l|}{$1 / 2 \mathrm{H} 1 / 2 \mathrm{O}$} \\
\hline MY & $7964 \pm 2096$ & $7332 \pm 1750$ & $7121 \pm 1634$ & $7242 \pm 1641$ & $6955 \pm 1528$ & $7783 \pm 2036$ \\
\hline FY & $287 \pm 67$ & $268 \pm 57$ & $265 \pm 57$ & $255 \pm 57$ & $260 \pm 55$ & $282 \pm 66$ \\
\hline PY & $255 \pm 69$ & $233 \pm 54$ & $232 \pm 54$ & $218 \pm 51$ & $223 \pm 50$ & $250 \pm 68$ \\
\hline \multicolumn{7}{|l|}{$1 / 4 \mathrm{H} 3 / 4 \mathrm{O}$} \\
\hline MY & $7223 \pm 1560$ & $6973 \pm 1534$ & $6226 \pm 1260$ & $6946 \pm 1498$ & $6029 \pm 1268$ & $6912 \pm 1562$ \\
\hline FY & $265 \pm 56$ & $255 \pm 56$ & $233 \pm 48$ & $250 \pm 52$ & $231 \pm 50$ & $255 \pm 56$ \\
\hline PY & $232 \pm 52$ & $228 \pm 49$ & $205 \pm 36$ & $228 \pm 55$ & $194 \pm 42$ & $224 \pm 52$ \\
\hline \multicolumn{7}{|l|}{ Other } \\
\hline MY & $7106 \pm 1627$ & $6825 \pm 1576$ & $5965 \pm 1425$ & $6605 \pm 1218$ & $5760 \pm 1304$ & $6663 \pm 1643$ \\
\hline $\mathrm{FY}$ & $259 \pm 57$ & $250 \pm 56$ & $223 \pm 51$ & $243 \pm 45$ & $219 \pm 50$ & $245 \pm 57$ \\
\hline PY & $228 \pm 56$ & $219 \pm 51$ & $209 \pm 49$ & $211 \pm 34$ & $191 \pm 44$ & $220 \pm 55$ \\
\hline \multicolumn{7}{|l|}{ All } \\
\hline MY & $7502 \pm 1829$ & $7053 \pm 1635$ & $6350 \pm 1559$ & $6878 \pm 1416$ & $6080 \pm 1451$ & $7146 \pm 1828$ \\
\hline FY & $273 \pm 62$ & $259 \pm 57$ & $237 \pm 57$ & $250 \pm 51$ & $231 \pm 55$ & $262 \pm 63$ \\
\hline PY & $242 \pm 61$ & $226 \pm 51$ & $220 \pm 51$ & $220 \pm 44$ & $202 \pm 49$ & $235 \pm 60$ \\
\hline
\end{tabular}

${ }^{1} \mathrm{H}=$ Holstein; $\mathrm{O}=$ other breeds.

${ }^{2}$ Subclass with one PY record.

the 9th and 10th regions of Southern Chile were sufficient enough for variation in these traits to be expressed in straightbred $\mathrm{H}$ and crossbred $\mathrm{H} \times \mathrm{O}$ cows. Estimates of $\mathrm{H}$ additive genetic and environmental variances for first lactation MY, FY, and PY were similar to values reported with US data (Dong et al., 1988; Van Vleck et al., 1988; Cienfuegos-Rivas et al., 1999; Costa et al., 2000).

Nonadditive $\mathrm{H} / \mathrm{O}$ genetic variances and covariances were small for the 3 dairy traits, indicating that the $\mathrm{H} /$ $\mathrm{O}$ interbreed interactive ability differed little among $\mathrm{H}$ and $\mathrm{H} \times \mathrm{O}$ sires in the subset of the Chilean population. Comparable estimates in temperate climates were unavailable in the literature. Under tropical conditions, however, Koonawootrittriron et al. (2002) obtained substantially larger estimates of $\mathrm{H} / \mathrm{O}$ genetic variances and covariances for first lactation 305-d milk and fat yields unadjusted to $\mathrm{ME}$ in a small field multibreed dataset in Thailand, where the $\mathrm{O}$ group was composed almost entirely of Bos indicus breeds. Although climate, management, and nutritional conditions in Thailand differed substantially from those in Chile, this might be an indication that larger amounts of $\mathrm{H} / \mathrm{O}$ nonadditive genetic variation for dairy production traits will occur in $\mathrm{H} \times$ Bos indicus than in $\mathrm{H} \times$ Bos taurus crosses.
In contrast, $\mathrm{H} / \mathrm{O}$ nonadditive regression means from the complete dataset had values of $192.4 \pm 3.2 \mathrm{~kg}$ for MY, $5.5 \pm 0.9 \mathrm{~kg}$ for FY, and $5.5 \pm 1.1 \mathrm{~kg}$ for PY, indicating some degree of heterosis for these traits in the Chilean multibreed dairy population. These heterosis values were somewhat lower ( $70 \%$ for MY, $43 \%$ for FY, and $53 \%$ for PY) than those found for first lactation 305-d milk, fat, and protein yields in $\mathrm{H} \times$ Dutch Friesian in The Netherlands (Janss and de Jong, 1999).

Multibreed variance and covariance components. Linear combinations of base variance and covariance estimates were used to compute multibreed genetic, environmental, and phenotypic variance and covariance estimates for 15 breed groups of sire $\times$ breed group of dam combinations. Weights for additive genetic and environmental multibreed variances and covariances were $\mathrm{H}$ - and $\mathrm{O}$-expected fractions in sires and dams. Weights for $\mathrm{H} / \mathrm{O}$ nonadditive genetic variances and covariances were equal to $1 / 2$ (the probability of one $\mathrm{H}$ and one $\mathrm{O}$ allele at one locus in the progeny of a sire of any $\mathrm{H}$ and $\mathrm{O}$ fractions mated to $1 / 2 \mathrm{H}$ dams). As interbreed additive genetic variances and covariances were assumed to be zero (preliminary analyses yielded estimates close to zero), multibreed additive and environmental variance and covariance estimates increased 
Table 3. Numbers of sires, dams, and cows in the subset of the Chilean multibreed population by breed group of sire $\times$ breed group of dam combination.

\begin{tabular}{|c|c|c|c|c|c|c|}
\hline \multirow{2}{*}{$\begin{array}{l}\text { Breed group } \\
\text { of dam }\end{array}$} & \multicolumn{6}{|c|}{ Breed group of sire ${ }^{1}$} \\
\hline & $\mathrm{H}$ & $3 / 4 \mathrm{H}^{1 / 4} \mathrm{O}$ & $1 / 2 \mathrm{H} 1 / 2 \mathrm{O}$ & $1 / 4 \mathrm{H}_{3}^{3} / 4 \mathrm{O}$ & $\mathrm{O}$ & All \\
\hline \multicolumn{7}{|l|}{$\mathrm{H}$} \\
\hline Sires, no. & 45 & 3 & 5 & 1 & 4 & 58 \\
\hline Dams, no. & 75 & 5 & 6 & 1 & 5 & 92 \\
\hline Cows, no. & 79 & 5 & 6 & 1 & 5 & 96 \\
\hline \multicolumn{7}{|l|}{$3 / 4 \mathrm{H} 1 / 4 \mathrm{O}$} \\
\hline Sires, no. & 89 & 4 & 8 & 2 & 12 & 115 \\
\hline Dams, no. & 287 & 10 & 38 & 8 & 40 & 376 \\
\hline Cows, no. & 297 & 10 & 38 & 8 & 40 & 393 \\
\hline \multicolumn{7}{|l|}{$1 / 2 \mathrm{H} 1 / 2 \mathrm{O}$} \\
\hline Sires, no. & 96 & 4 & 10 & 2 & 18 & 130 \\
\hline Dams, no. & 586 & 14 & 76 & 22 & 98 & 792 \\
\hline Cows, no. & 618 & 14 & 77 & 23 & 98 & 830 \\
\hline \multicolumn{7}{|l|}{$1 / 4 \mathrm{H} 3 / 4 \mathrm{O}$} \\
\hline Sires, no. & 77 & 4 & 9 & 2 & 16 & 108 \\
\hline Dams, no. & 414 & 14 & 42 & 24 & 79 & 565 \\
\hline Cows, no. & 434 & 14 & 42 & 24 & 82 & 596 \\
\hline \multicolumn{7}{|l|}{ Other } \\
\hline Sires, no. & 98 & 5 & 9 & 2 & 19 & 133 \\
\hline Dams, no. & 676 & 27 & 74 & 49 & 147 & 950 \\
\hline Cows, no. & 1002 & 48 & 101 & 50 & 200 & 1401 \\
\hline \multicolumn{7}{|l|}{ All } \\
\hline Sires, no. & 113 & 5 & 10 & 2 & 19 & 149 \\
\hline Dams, no. & 2038 & 70 & 236 & 104 & 369 & 2775 \\
\hline Cows, no. & 2430 & 91 & 264 & 106 & 425 & 3316 \\
\hline
\end{tabular}

${ }^{1} \mathrm{H}=$ Holstein; $\mathrm{O}=$ other breeds.

linearly from $\mathrm{O}$ to $\mathrm{H}$. Thus, all additive genetic and environmental variances and covariances will have values intermediate between those for $\mathrm{H}$ and $\mathrm{O}$. Because the main goal of Chilean producers was to upgrade to $\mathrm{H}$, multibreed variance and covariance estimates for matings of $\mathrm{H}$ sires to $3 \mathrm{H} \times \mathrm{O}$ crossbred and $\mathrm{O}$ group of dams are presented in Table 5 .

\section{Estimates of Variance Ratios and Correlations}

Multibreed heritabilities and genetic correlations for straightbred $\mathrm{H}, \mathrm{H} \times 3 / 4 \mathrm{H} 1 / 4 \mathrm{O}, \mathrm{H} \times 1 / 2 \mathrm{H} 1 / 2 \mathrm{O}, \mathrm{H} \times 1 / 4 \mathrm{H}$ $3 / 4 \mathrm{O}, \mathrm{H} \times \mathrm{O}$, and $\mathrm{O}$ are shown in Table 6 .
Heritability estimates for MY and FY were slightly smaller in $\mathrm{H}$ than in $\mathrm{O}$ because of proportionally larger environmental variance values in $\mathrm{H}$. The opposite occurred for PY, hence, the higher estimate of heritability in $\mathrm{H}$ than in $\mathrm{O}$. Heritability estimates for $\mathrm{H}$ were comparable with those obtained using data from the US and other countries (Van Vleck et al., 1988; Costa et al., 2000; Weigel et al., 2001). Additive genetic correlations between MY, FY, and PY were similar in $\mathrm{H}$ and $\mathrm{O}$ $(>0.60)$. An exception was between FY and PY, which was higher in $\mathrm{H}(0.56)$ than in $\mathrm{O}(0.19)$. The additive genetic correlation values of 0.99 between MY and PY for all mating combinations in Table 6 were due to the

Table 4. Estimates of base additive genetic, nonadditive genetic, environmental, and phenotypic variances and covariances for 305-d mature equivalent milk yield (MY), fat yield (FY), and protein yield (PY).

\begin{tabular}{lrrrrrr}
\hline Effect $^{1}$ & MY, MY & MY, FY & MY, PY & FY, FY & FY, PY & PY, PY \\
\cline { 2 - 4 } & \multicolumn{7}{c}{$\left(\mathrm{kg}^{2}\right)$} & & & \\
\cline { 2 - 4 } Additive H & 453,404 & 10,394 & 11,455 & 529 & 220 & 295 \\
Additive O & 404,259 & 8653 & 9790 & 488 & 67 & 242 \\
Nonadditive H/O & 10,017 & 74 & 96 & 35 & 2.7 & 19 \\
Environmental H & $1,000,214$ & 32,224 & 25,871 & 1311 & 1004 & 940 \\
Environmental O & 772,934 & 22,739 & 23,992 & 831 & 967 & 1147 \\
Phenotypic H & $1,453,618$ & 42,618 & 37,326 & 1840 & 1224 & 1236 \\
Phenotypic O & $1,177,193$ & 31,392 & 33,781 & 1319 & 1033 & 1389 \\
\hline
\end{tabular}

\footnotetext{
${ }^{1} \mathrm{H}=$ Holstein, $\mathrm{O}=$ other breeds, and $\mathrm{H} / \mathrm{O}=$ intralocus $\mathrm{H} / \mathrm{O}$.
} 
Table 5. Estimates of multibreed additive genetic, nonadditive genetic, environmental, and phenotypic variances and covariances for 305-d mature equivalent milk yield (MY), fat yield (FY), and protein yield $(\mathrm{PY})$ in 4 Holstein $(\mathrm{H}) \times$ breed group of dam combinations.

\begin{tabular}{|c|c|c|c|c|c|c|}
\hline Mating $^{1}$ & MY, MY & MY, FY & MY, PY & FY, FY & FY, PY & PY, PY \\
\hline & & & - $(\mathrm{k}$ & & & \\
\hline \multicolumn{7}{|l|}{$\mathrm{H} \times 3 / 4 \mathrm{H}^{1 / 4} \mathrm{O}$} \\
\hline Additive & 447,261 & 10,177 & 11,247 & 524 & 201 & 289 \\
\hline Nonadditive & 2504 & 19 & 24 & 9 & 0.7 & 5 \\
\hline Environmental & 971,804 & 31,038 & 25,636 & 1251 & 999 & 966 \\
\hline Phenotypic & $1,421,569$ & 41,234 & 36,907 & 1784 & 1201 & 1260 \\
\hline \multicolumn{7}{|l|}{$\mathrm{H} \times 1 / 2 \mathrm{H}^{1 / 2} \mathrm{O}$} \\
\hline Additive & 441,118 & 9959 & 11,039 & 519 & 182 & 282 \\
\hline Nonadditive & 5008 & 37 & 48 & 18 & 1.3 & 9 \\
\hline Environmental & 943,394 & 29,853 & 25,401 & 1191 & 995 & 992 \\
\hline Phenotypic & $1,389,520$ & 39,849 & 36,488 & 1717 & 1178 & 1283 \\
\hline \multicolumn{7}{|l|}{$\mathrm{H} \times 1 / 4 \mathrm{H}^{3 / 4} \mathrm{O}$} \\
\hline Additive & 434,975 & 9741 & 10,831 & 514 & 162 & 275 \\
\hline Nonadditive & 7512 & 55 & 72 & 26 & 2.0 & 14 \\
\hline Environmental & 914,984 & 28,667 & 25,166 & 1131 & 990 & 1018 \\
\hline Phenotypic & $1,357,471$ & 38,464 & 36,069 & 1671 & 1154 & 1307 \\
\hline \multicolumn{7}{|l|}{$\mathrm{H} \times \mathrm{O}$} \\
\hline Additive & 428,832 & 9524 & 10,622 & 508 & 143 & 269 \\
\hline Nonadditive & 10,017 & 74 & 96 & 35 & 2.7 & 19 \\
\hline Environmental & 868,574 & 27,481 & 24,931 & 1071 & 985 & 1044 \\
\hline Phenotypic & $1,325,422$ & 37,079 & 35,650 & 1615 & 1131 & 13,301 \\
\hline
\end{tabular}

${ }^{1} \mathrm{O}=$ other breeds.

Table 6. Estimates of multibreed heritabilities and genetic, environmental, and phenotypic correlations for 305-d mature equivalent milk yield (MY), fat yield (FY), and protein yield (PY) in 6 breed group of sire $\times$ breed group of dam combinations. ${ }^{1}$

\begin{tabular}{|c|c|c|c|}
\hline Mating $^{2}$ & MY & FY & PY \\
\hline \multicolumn{4}{|l|}{$\mathrm{H} \times \mathrm{H}$} \\
\hline MY & 0.31 & 0.67 & $0.99^{3}$ \\
\hline FY & $0.89(0.82)$ & 0.29 & 0.56 \\
\hline PY & $0.84(0.88)$ & $0.90(0.81)$ & 0.24 \\
\hline \multicolumn{4}{|c|}{$\mathrm{H} \times 3 / 4 \mathrm{H} 1 / 4 \mathrm{O}$} \\
\hline MY & 0.31 & 0.66 & $0.99^{3}$ \\
\hline $\mathrm{FY}$ & $0.82(0.89)$ & 0.29 & 0.52 \\
\hline PY & $0.87(0.82)$ & $0.80(0.91)$ & 0.23 \\
\hline \multicolumn{4}{|c|}{$\mathrm{H} \times 1 / 2 \mathrm{H} 1 / 2 \mathrm{O}$} \\
\hline MY & 0.32 & 0.66 & $0.99^{3}$ \\
\hline FY & $0.89(0.81)$ & 0.30 & 0.47 \\
\hline PY & $0.83(0.86)$ & $0.91(0.79)$ & 0.22 \\
\hline \multicolumn{4}{|c|}{$\mathrm{H} \times 1 / 4 \mathrm{H} 3 / 4 \mathrm{O}$} \\
\hline MY & 0.32 & 0.65 & $0.99^{3}$ \\
\hline FY & $0.89(0.81)$ & 0.31 & 0.43 \\
\hline PY & $0.82(0.86)$ & $0.92(0.78)$ & 0.21 \\
\hline \multicolumn{4}{|l|}{$\mathrm{H} \times \mathrm{O}$} \\
\hline MY & 0.32 & 0.65 & $0.99^{3}$ \\
\hline FY & $0.89(0.80)$ & 0.31 & 0.39 \\
\hline PY & $0.82(0.85)$ & $0.93(0.77)$ & 0.21 \\
\hline \multicolumn{4}{|l|}{$\mathrm{O} \times \mathrm{O}$} \\
\hline MY & 0.34 & 0.62 & $0.99^{3}$ \\
\hline FY & $0.90(0.80)$ & 0.37 & 0.19 \\
\hline PY & $0.81(0.84)$ & $0.99(0.76)$ & 0.17 \\
\hline
\end{tabular}

${ }^{1}$ Heritabilities are on the diagonal, genetic correlations are above diagonal, environmental correlations are below diagonal, and phenotypic correlations are presented in parentheses below diagonal.

${ }^{2} \mathrm{H}=$ Holstein; $\mathrm{O}=$ other breeds.

${ }^{3}$ Value caused by restriction imposed on covariance solutions. restriction imposed on covariance estimates to preserve the positive definiteness of the additive genetic covariance matrix for MY, FY, and PY. Environmental correlations were slightly larger than phenotypic correlations, comparable in $\mathrm{H}$ and $\mathrm{O}$, but all were $>0.76$. Because of the extremely small $\mathrm{H} / \mathrm{O}$ nonadditive variances and covariances, interactibilities and nonadditive genetic correlations were near zero for all traits. This was in contrast to the interactibility value of 0.17 obtained by Koonawootrittriron et al. (2002) in the $\mathrm{H} \times \mathrm{O}(\mathrm{O}$ mostly Bos indicus) Thai multibreed dataset.

\section{Genetic Trends}

Estimates of genetic parameters from the subset analyses were applied to the complete Chilean dataset to compute additive, interbreed nonadditive, and total (additive plus nonadditive) multibreed genetic predictions for all sires and maternal grandsires. Interbreed nonadditive genetic predictions assumed sires were mated to $\mathrm{F} 1$ dams. They were small (about $1 / 5$ ) relative to additive genetic predictions. Because of it, there was little difference between the graphs of additive and total MPTA yearly means. Subclass-weighted sire plus maternal grandsire, unweighted sire, and unweighted maternal grandsire genetic trends were computed for all traits and genetic effects per breed group and for the complete population. Upward genetic trends existed in all straightbred and crossbred groups for weighted and unweighted yearly means for all traits and effects, ex- 


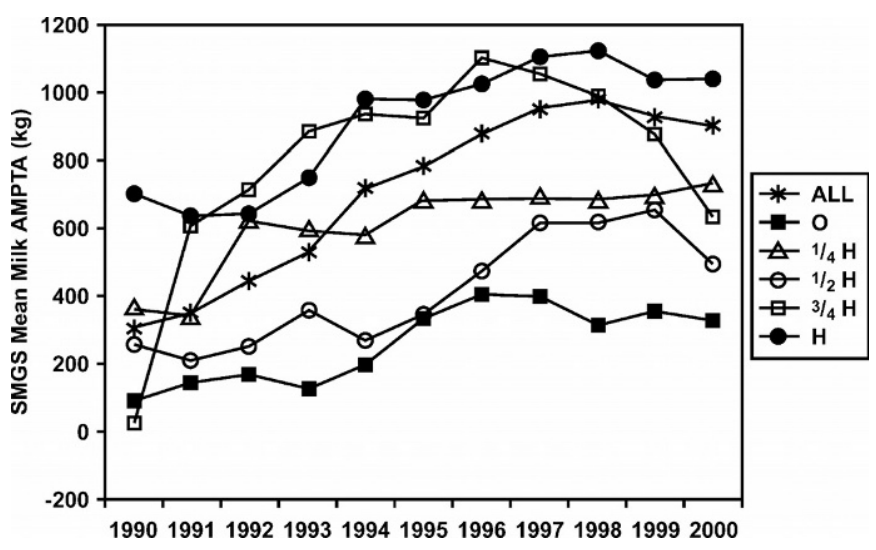

Figure 1. Weighted yearly mean milk additive multibreed PTA (AMPTA) of sires plus maternal grandsires (SMGS) for Holstein $(\mathrm{H})$, other $(\mathrm{O}), 1 / 4 \mathrm{H} 3 / 4 \mathrm{O}(1 / 4 \mathrm{H}), 1 / 2 \mathrm{H} 1 / 2 \mathrm{O}(1 / 2 \mathrm{H}), 3 / 4 \mathrm{H} 1 / 4 \mathrm{O}(3 / 4 \mathrm{H})$, and sires and maternal grandsires of all breed combinations (ALL).

cept for the sire plus maternal grandsire and the sire means of PY in the $1 / 4 \mathrm{H}$ breed group. Because of small numbers, standard errors of yearly means for all traits and effects in the $1 / 4 \mathrm{H}$ breed group were substantially larger than for all $\mathrm{O}$ groups in the population. Thus, ranges of yearly mean standard errors are reported separately for this breed group.

Weighted sire plus maternal grandsire genetic trends. These trends reflect sire usage and maternal grandsire representation in the Chilean cow population between 1990 and 2000. They could also be considered an approximation to changes in additive, interbreed nonadditive, and total mean cow-predicted genetic values during this period. Weighted yearly means were computed as the sum of each cow's sire MPTA plus onehalf her maternal grandsire MPTA divided by the sum of the number of daughters plus 0.5 times the number of granddaughters present in a given year.

Figure 1 shows the weighted sire plus maternal grandsire genetic trends for MY additive MPTA for each straightbred and crossbred group and for the complete population. Except for a scaling factor, sire plus maternal grandsire figures for FY and PY additive genetic trends were similar to Figure 1.

All breed groups showed an upward additive genetic trend for MY between 1990 and 2000. Changes in yearly milk additive genetic means were $339 \mathrm{~kg}$ for $\mathrm{H}, 240 \mathrm{~kg}$ for $\mathrm{O}, 606 \mathrm{~kg}$ for $3 / 4 \mathrm{H}, 240 \mathrm{~kg}$ for $1 / 2 \mathrm{H}, 367 \mathrm{~kg}$ for $1 / 4 \mathrm{H}$, and $598 \mathrm{~kg}$ for the complete population. Changes in additive yearly means for FY were $12 \mathrm{~kg}$ in $\mathrm{H}, 19 \mathrm{~kg}$ in $\mathrm{O}, 14 \mathrm{~kg}$ in $3 / 4 \mathrm{H}, 10 \mathrm{~kg}$ in $1 / 2 \mathrm{H}, 14 \mathrm{~kg}$ in $1 / 4 \mathrm{H}$, and $20 \mathrm{~kg}$ in the complete population. For PY, changes were $13 \mathrm{~kg}$ in $\mathrm{H}, 20 \mathrm{~kg}$ in $\mathrm{O}, 12 \mathrm{~kg}$ in $3 / 4 \mathrm{H}, 9 \mathrm{~kg}$ in $1 / 2 \mathrm{H},-6$ $\mathrm{kg}$ in $1 / 4 \mathrm{H}$, and $17 \mathrm{~kg}$ in the complete population. Thus, all traits and all breed groups, except for $1 / 4 \mathrm{H}$ for PY, had positive trends. Positive additive genetic trends in all breed groups but one suggest that Chilean producers used increasingly better sires and kept cows that were granddaughters of better maternal grandsires, regardless of their breed composition. The decreasing trend observed for MY primarily for the last $3 \mathrm{yr}$ (1998 to 2000) occurred probably because dairy producers in these 2 regions chose $\mathrm{H}$ sires whose daughters were expected to produce amounts of milk that would require little change to the prevalent production system based on mostly pasture plus some concentrate. This was likely influenced by low milk prices in the 9th and 10th regions of Chile between 1995 and 2000 (Moya et al., 1998; V. Esnaola, 2003, personal communication) and because most dairymen in these regions prefer to produce milk based on pasture plus limited amounts of concentrate.

Additive yearly means for straightbred groups and crossbred groups $1 / 2 \mathrm{H}$ and above had standard errors ranging from 3 to $35 \mathrm{~kg}$ for MY, from 0.1 to $1.5 \mathrm{~kg}$ for $\mathrm{FY}$, and from 0.1 to $4.1 \mathrm{~kg}$ for PY, whereas, for $1 / 4 \mathrm{H}$, ranges went from 38 to $60 \mathrm{~kg}$ for MY, from 1.2 to 5.2 $\mathrm{kg}$ for FY, and from 2.8 to $11.7 \mathrm{~kg}$ for PY.

Considering that sire plus maternal grandsire yearly means account for $75 \%$ of cow breeding values, changes in $\mathrm{H}$ yearly means between 1990 and 2000 in Chile were $394 \mathrm{~kg}$ for MY, $9 \mathrm{~kg}$ for FY, and $7 \mathrm{~kg}$ for PY, which was $<0.75$ times the change in mean cow breeding value in the US (AIPL, 2003) during this period. This indicates that Chilean cattlemen bought semen from $\mathrm{H}$ sires whose PTA were above average, but not necessarily the highest available in the US. Another explanation is that because nutritional systems in the 9th and 10th regions of Southern Chile used a mixture of improved pastures and concentrate, daughters of some top $\mathrm{H}$ sires expressed less favorably their genetic potential under these conditions than their half sisters in the US that received higher levels of concentrate.

Interbreed nonadditive genetic trends for all traits in all breed groups and in the complete population were positive and about one-fifth of additive genetic trends. Figure 2 shows interbreed genetic trends for MY. Sires from the $\mathrm{H}, 3 / 4 \mathrm{H}$, and $\mathrm{O}$ groups tended to have similar combining abilities. Conversely, the mean combining ability of $1 / 4 \mathrm{H}$ sires tended to be above, and that of $1 / 2$ $\mathrm{H}$ sires below, that of sires from $\mathrm{O}$ groups. As with additive genetic trends, aside from a scaling factor, interbreed nonadditive genetic trends for FY and PY were similar to those in Figure 2.

Changes in interbreed nonadditive yearly means between 2000 and 1990 for MY, FY, and PY were 132, 12 , and $4 \mathrm{~kg}$ in $\mathrm{H} ; 45,5$, and $2 \mathrm{~kg}$ in $\mathrm{O} ; 149,7$, and 6 $\mathrm{kg}$ in $3 / 4 \mathrm{H} ; 91,4$, and $3 \mathrm{~kg}$ in $1 / 2 \mathrm{H} ; 16,3$, and $2 \mathrm{~kg}$ in 


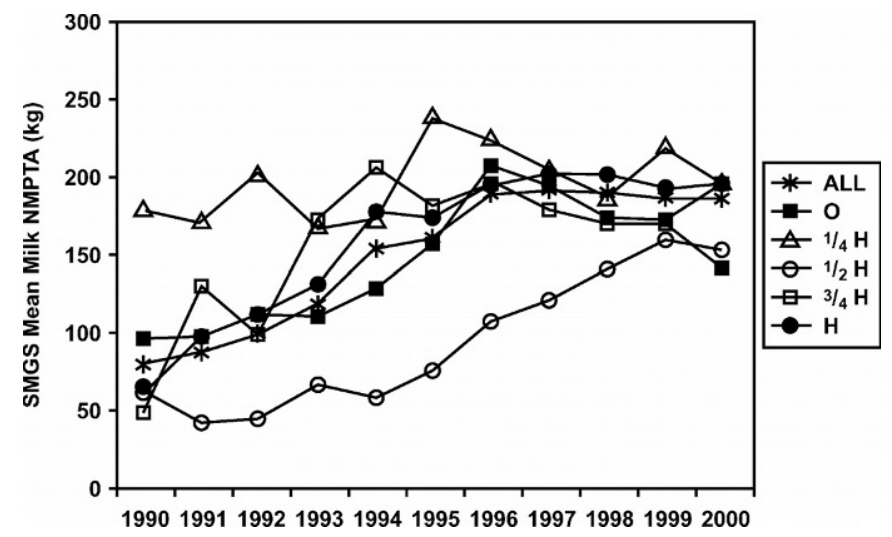

Figure 2. Weighted yearly mean milk interbreed nonadditive multibreed PTA (NMPTA) of sires plus maternal grandsires (SMGS) for Holstein $(\mathrm{H})$, other $(\mathrm{O}), 1 / 4 \mathrm{H} 3 / 4 \mathrm{O}(1 / 4 \mathrm{H}), 1 / 2 \mathrm{H} 1 / 2 \mathrm{O}(1 / 2 \mathrm{H}), 3 / 4 \mathrm{H} 1 / 4$ $\mathrm{O}(3 / 4 \mathrm{H})$, and sires and maternal grandsires of all breed combinations (ALL).

$1 / 4 \mathrm{H}$; and 107,4 , and $3 \mathrm{~kg}$ in the complete population, respectively.

These positive interbreed nonadditive genetic trends may be an indication that $\mathrm{H}$ and $\mathrm{O}$ combining ability improved between 1990 and 2000. However, no restriction on the breed composition of sires and dams represented in contemporary groups was imposed on the complete Chilean dataset used to obtain the multibreed predictions used for genetic trends. Thus, another possibility is that this interbreed nonadditive genetic trend may be due, at least in part, to some degree of confounding between additive and nonadditive genetic effects.

Standard errors of nonadditive yearly means for $\mathrm{H}$, $\mathrm{O}, 3 / 4 \mathrm{H}$, and $1 / 2 \mathrm{H}$ ranged from 1 to $10 \mathrm{~kg}$ for $\mathrm{MY}$, from 0.1 to $0.2 \mathrm{~kg}$ for FY, and from 0.1 to $0.5 \mathrm{~kg}$ for PY, and, for $1 / 4 \mathrm{H}$, they ranged from 6 to $30 \mathrm{~kg}$ for MY, from 0.1 to $0.2 \mathrm{~kg}$ for FY, and from 0.3 to $2.1 \mathrm{~kg}$ for PY.

Because of the small values of interbreed genetic predictions relative to additive genetic predictions, total genetic means per year were similar to yearly additive genetic means and so were the figures of genetic trends for total genetic effects. The $1 / 2 \mathrm{H}$ breed group had the largest differences between additive and total yearly means. Changes in total genetic means between 1990 and 2000 for MY, FY, and PY were 522,15 , and $13 \mathrm{~kg}$ in $\mathrm{H} ; 164,18$, and $8 \mathrm{~kg}$ in $\mathrm{O} ; 815,37$, and $27 \mathrm{~kg}$ in $3 / 4$ $\mathrm{H} ; 388,15$, and $11 \mathrm{~kg}$ in $1 / 2 \mathrm{H} ; 15,1$, and $-13 \mathrm{~kg}$ in $1 / 4$ $\mathrm{H}$; and 676,23 , and $17 \mathrm{~kg}$ in the complete population, respectively. Most standard errors of yearly means ranged from 3 to $44 \mathrm{~kg}$ for $\mathrm{MY}$, from 0.1 to $3.3 \mathrm{~kg}$ for $\mathrm{FY}$, and from 0.1 to $3.1 \mathrm{~kg}$ for PY.

Unweighted sire and maternal grandsire genetic trends. These trends depict changes in mean additive, interbreed nonadditive, and total MPTA of sires used and maternal grandsires represented in the

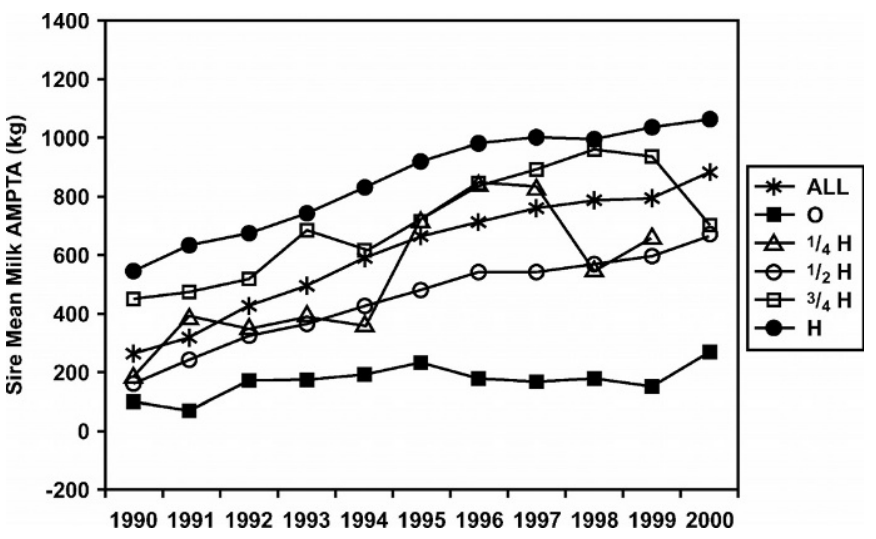

Figure 3. Unweighted yearly mean milk additive multibreed PTA (AMPTA) of sires for Holstein $(\mathrm{H})$, other $(\mathrm{O}), 1 / 4 \mathrm{H} 3 / 4 \mathrm{O}(1 / 4 \mathrm{H}), 1 / 2 \mathrm{H}$ $1 / 2 \mathrm{O}(1 / 2 \mathrm{H}), 3 / 4 \mathrm{H}^{1 / 4} \mathrm{O}(3 / 4 \mathrm{H})$, and sires of all breed combinations (ALL).

Chilean dataset that occurred between 1990 and 2000 . Only figures for unweighted sire genetic trends are shown here. Standard errors were somewhat higher for sire than for maternal grandsire yearly means, and they were usually 2 to 5 times larger than those of weighted sire plus maternal grandsire yearly means.

Unweighted sire additive yearly means are shown in Figure 3 . The vast majority of sire additive yearly means were somewhat smaller than sire plus maternal grandsire weighted additive yearly means for all breed groups and for the complete population. This may be an indication that superior sires were used more often and mated to superior cows (preferential mating) and that these superior cows were kept in the herd longer. For the complete population, differences in MY additive yearly means ranged from $19 \mathrm{~kg}$ (in 2000) to $199 \mathrm{~kg}$ (in 1998). The largest differences occurred for $\mathrm{O}$ and crossbred group-of-sire $\times$ year subclasses with the least amount of information. A similar situation existed for FY and PY. Conversely, most of the sire additive yearly means for all traits were substantially larger than maternal grandsire yearly means, suggesting that Chilean producers used increasingly superior sires (particularly $\mathrm{H})$ over time. In the complete population, this advantage ranged between $104 \mathrm{~kg}$ (in 2000) and $359 \mathrm{~kg}$ (in 1995) for MY. Except for 2000 (and also 1999 for O), sire additive yearly means for all breed groups were larger than maternal grandsire yearly means.

Graphs for FY and PY showed a similar pattern to MY. These unweighted additive genetic trends indicate that Chilean cattlemen chose straightbred and crossbred sires of increasingly better additive MPTA over time.

Differences between 2000 and 1990 unweighted sire additive yearly means for MY, FY, and PY were 508, 16 , and $18 \mathrm{~kg}$ in $\mathrm{H} ; 165,10$, and $12 \mathrm{~kg}$ in $\mathrm{O} ; 126,4$, and 


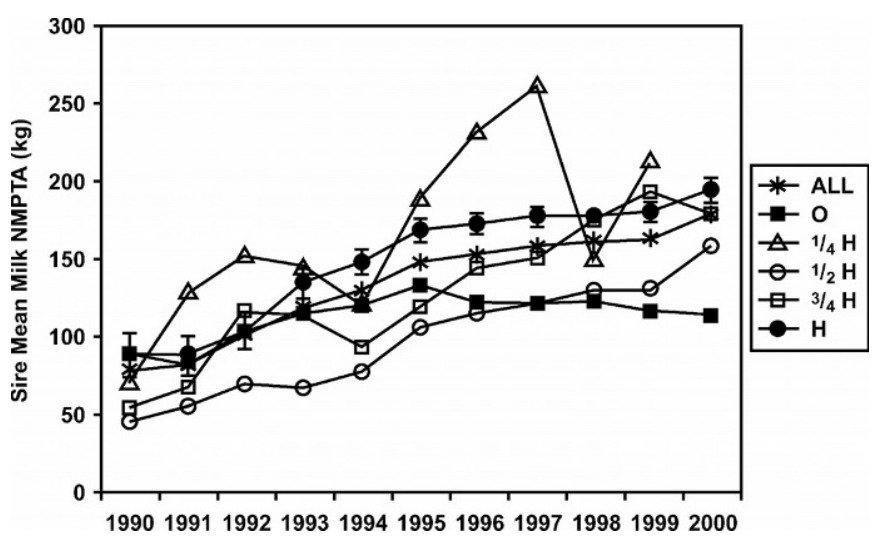

Figure 4. Unweighted yearly mean milk interbreed nonadditive multibreed PTA (NMPTA) of sires for Holstein $(\mathrm{H})$, other $(\mathrm{O}), 1 / 4 \mathrm{H}$ $3 / 4 \mathrm{O}(1 / 4 \mathrm{H}), 1 / 2 \mathrm{H} 1 / 2 \mathrm{O}(1 / 2 \mathrm{H}), 3 / 4 \mathrm{H} 1 / 4 \mathrm{O}(3 / 4 \mathrm{H})$, and sires of all breed combinations (ALL).

$10 \mathrm{~kg}$ in $3 / 4 \mathrm{H} ; 510,19$, and $19 \mathrm{~kg}$ in $1 / 2 \mathrm{H} ; 478,25$, and $0 \mathrm{~kg}$ in $1 / 4 \mathrm{H}$; and 624,20 , and $20 \mathrm{~kg}$ in the population. The corresponding maternal grandsire changes for MY, FY, and PY were 552, 18, and $15 \mathrm{~kg}$ in $\mathrm{H} ; 309,18$, and $15 \mathrm{~kg}$ in $\mathrm{O} ; 612,17$, and $13 \mathrm{~kg}$ in $3 / 4 \mathrm{H} ; 422,18$, and 0 $\mathrm{kg}$ in $1 / 2 \mathrm{H} ; 788,27$, and $10 \mathrm{~kg}$ in $1 / 4 \mathrm{H}$; and 689, 24, and $17 \mathrm{~kg}$ in the complete population, respectively.

Changes in $\mathrm{H}$ sire unweighted additive genetic yearly means between 1990 and 2000 in Chile were $59 \mathrm{~kg}$ less for MY, $1 \mathrm{~kg}$ more for FY, and $4 \mathrm{~kg}$ more for PY than those provided for $\mathrm{H}$ sires in the US by AIPL (2003). This again reconfirms that Chilean dairymen were purchasing $\mathrm{H}$ semen from good, but not necessarily the best, sires available in the US. Price might have been one consideration. Another reason might have been that Chilean producers wanted to keep a production system based on pasture and concentrate, thus they did not want to have $\mathrm{H}$ sires whose daughters required high levels of concentrate to achieve their production potential. It should again be mentioned that perhaps the less intensive concentrate feeding practices in the 9th and 10th regions of Southern Chile might have prevented daughters of top $\mathrm{H}$ sires from achieving the same production level as in the US.

Graphs of unweighted nonadditive yearly means showed positive genetic trends both for sires and for maternal grandsires. Standard errors were similar to those of weighted sire plus maternal grandsire yearly means. Figure 4 shows MY unweighted nonadditive genetic yearly means for sires. The pattern of genetic trend lines tended to follow closely the one found for weighted nonadditive genetic yearly means for sires plus maternal grandsires. Yearly means for $1 / 2 \mathrm{H}$ were usually below, and those for $1 / 4 \mathrm{H}$ sires were usually above, the means of other breed groups.
The divergence in combining ability between $\mathrm{H}$ and $\mathrm{O}$ sires was broader among sire unweighted nonadditive yearly means than that of weighted sire plus maternal grandsires and unweighted sire nonadditive yearly means. This may be an indication that 1) $\mathrm{H}$ sires had better combining ability than $\mathrm{O}$ sires, 2 ) there was some biological association between additive and nonadditive genetic combining abilities, and 3) there was some confounding between additive and nonadditive MPTA.

As it happened with additive yearly means, most unweighted sire nonadditive yearly means were smaller than weighted sire plus maternal grandsire nonadditive yearly means and larger than unweighted maternal grandsire nonadditive yearly means. This suggests that Chilean dairymen chose sires with progressively better combining abilities over time and that they preferentially mated superior sires to superior dams. However, only intrabreed PTA (primarily from the US, Canada, and Chile) were available to select sires, which suggests the possibility of a positive association between additive and nonadditive MPTA.

Unweighted sire nonadditive yearly means for MY in the complete population were from $-0.1 \mathrm{~kg}$ (in 1992) to $-36 \mathrm{~kg}$ (in 1996) below weighted sire plus maternal grandsire and from $24 \mathrm{~kg}$ (in 1991) to $65 \mathrm{~kg}$ (in 1995) above unweighted maternal grandsire nonadditive yearly means. Changes in interbreed nonadditive yearly means between 2000 and 1990 for MY, FY, and PY were 107, 3, and $3 \mathrm{~kg}$ in $\mathrm{H} ; 25,3$, and $2 \mathrm{~kg}$ in $\mathrm{O}$; 126,6 , and $4 \mathrm{~kg}$ in $3 / 4 \mathrm{H} ; 114,5$, and $5 \mathrm{~kg}$ in $1 / 2 \mathrm{H} ; 143$, 5 , and $2 \mathrm{~kg}$ in $1 / 4 \mathrm{H}$; and 101,3 , and $4 \mathrm{~kg}$ in the complete population. Maternal grandsire changes in nonadditive yearly means for MY, FY, and PY were 135,5 , and 4 $\mathrm{kg}$ in $\mathrm{H} ; 80,5$, and $2 \mathrm{~kg}$ in $\mathrm{O} ; 66,1$, and $1 \mathrm{~kg}$ in $3 / 4 \mathrm{H}$; 77,3 , and $2 \mathrm{~kg}$ in $1 / 2 \mathrm{H} ; 179,6$, and $5 \mathrm{~kg}$ in $1 / 4 \mathrm{H}$; and 101,4 , and $2 \mathrm{~kg}$ in the complete population.

Genetic trends for unweighted sire and maternal grandsire total MPTA yearly means were similar to the corresponding sire and maternal grandsire additive MPTA yearly means because of the proportionally small values of nonadditive MPTA. Changes in sire unweighted total genetic means between 1990 and 2000 for MY, FY, and PY were 508, 14, and $15 \mathrm{~kg}$ in H; 68, 8 , and $7 \mathrm{~kg}$ in $\mathrm{O} ; 569,28$, and $19 \mathrm{~kg}$ in $3 / 4 \mathrm{H} ; 484,19$, and $18 \mathrm{~kg}$ in $1 / 2 \mathrm{H} ; 464,17$, and $4 \mathrm{~kg}$ in $1 / 4 \mathrm{H}$; and 633, 20, and $20 \mathrm{~kg}$ in the complete population. Corresponding changes for MY, FY, and PY in maternal grandsires were 591,19 , and $15 \mathrm{~kg}$ in $\mathrm{H} ; 318,17$, and $8 \mathrm{~kg}$ in $\mathrm{O}$; 479,15 , and $14 \mathrm{~kg}$ in $3 / 4 \mathrm{H} ; 439,18$, and $15 \mathrm{~kg}$ in $1 / 2 \mathrm{H}$; 698, 25, and $22 \mathrm{~kg}$ in $1 / 4 \mathrm{H}$; and 671, 24, and $15 \mathrm{~kg}$ in the complete population. Standard errors of sire and maternal grandsire total yearly means were similar to those for additive yearly means. 


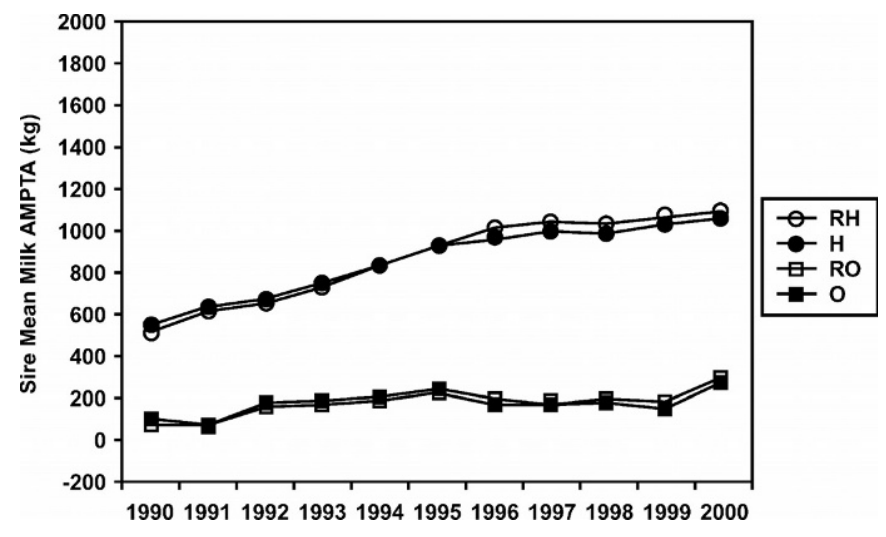

Figure 5. Regression and subclass unweighted yearly mean milk additive multibreed PTA (AMPTA) of sires for Holstein $(\mathrm{H})$ and other breeds $(\mathrm{O}) . \mathrm{RH}=$ Regression $\mathrm{H}, \mathrm{H}=$ subclass $\mathrm{H}, \mathrm{RO}=$ regression $\mathrm{O}$, and $\mathrm{O}=$ subclass $\mathrm{O}$.

Regression additive genetic trends. The purpose of computing $\mathrm{H}$ and $\mathrm{O}$ yearly means using regression procedures was to account for the effects of all $\mathrm{H}$ and $\mathrm{O}$ alleles in the Chilean multibreed population when computing additive $\mathrm{H}$ and $\mathrm{O}$ yearly means. This implies using information from straightbred and crossbred animals when computing additive $\mathrm{H}$ and $\mathrm{O}$ yearly means by regression. Regression and subclass yearly means should be alike if the sample of $\mathrm{H}$ and $\mathrm{O}$ alleles from sires in the $\mathrm{H}$ and $\mathrm{O}$ groups had similar genetic value to the sample of $\mathrm{H}$ and $\mathrm{O}$ alleles present in sires from $\mathrm{H} \times \mathrm{O}$ crossbred groups. Figure 5 shows regression and subclass unweighted MY additive yearly means for sires, and Figure 6 shows that for maternal grandsires.

The regression and subclass lines for $\mathrm{H}$ and $\mathrm{O}$ were very close for unweighted sire additive yearly means (Figure 5), but not for unweighted maternal grandsire

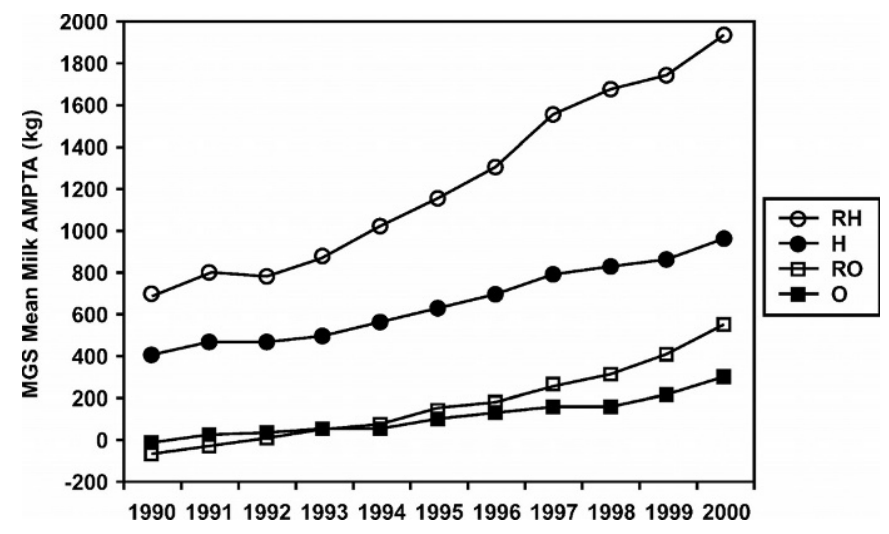

Figure 6. Regression and subclass unweighted yearly mean milk additive multibreed PTA (AMPTA) of maternal grandsires for Holstein $(\mathrm{H})$ and other breeds $(\mathrm{O}) . \mathrm{RH}=$ Regression $\mathrm{H}, \mathrm{H}=$ subclass $\mathrm{H}$, $\mathrm{RO}=$ regression $\mathrm{O}$, and $\mathrm{O}=$ subclass $\mathrm{O}$. additive yearly means (Figure 6), and differences between regression and subclass lines were larger for $\mathrm{H}$ than for O. Figures for FY and PY showed a similar pattern, which suggests that Chilean cattlemen used $\mathrm{H}$ sires of substantially higher additive genetic value to produce crossbred animals than those used to sire straightbred $\mathrm{H}$.

This dissimilar mating strategy for straightbred and crossbred animals may be related to a goal of producing a type of dairy animal suited to the prevalent production conditions in the 9 th and 10th regions of Southern Chile at that time. This goal appears to have been to increase milk production from crossbred cows as quickly as possible while moderately increasing the level of production from $\mathrm{H}$ cows.

\section{CONCLUSIONS}

There was little difference in the estimates of additive genetic parameters in $\mathrm{H}$ and $\mathrm{O}$ groups in the Chilean multibreed population. Holstein genetic parameter estimates were similar to those reported elsewhere. Interbreed nonadditive genetic variation was small, unlike heterosis estimates that were in line with estimates found in the literature. Weighted and unweighted genetic trends indicated that Chilean cattle producers 1) followed the genetic evaluation results in Canada and the US and chose sires of higher predicted abilities for milk traits over time, 2) chose crossbred bulls that were sons and grandsons of superior Holstein sires, 3) used sires appropriate for their pasture plus concentrate production system more frequently, 4) kept dams of better sires longer, and 5) benefited from genetic trends for milk traits in the US and Canadian $\mathrm{H}$ populations.

\section{REFERENCES}

Animal Improvement Programs Laboratory. 2003. Genotypic and phenotypic trends. Online. Available: http://aipl.arsusda.gov/dynamic/trend/current/trndx.html. Accessed August 8, 2003.

Barría, N., J. Aumann, H.-U. Graser, and G. Stolzenbach. 1995. Genetic evaluation of dairy sires of different origins and genetic trend for milk production in Region X (Chile). Adv. Anim. Prod. 20:67-78.

Barría, N., F. Santibañez, G. Stolzenbach, and A. Jara. 2001. Effect of the "Holsteinization" on production traits in a population of dual-purpose cows in Region X (Chile). Proc. 17th Latin Am. Assoc. Anim. Prod., La Habana, Cuba DP8:942-945.

Barría, N., and G. Stolzenbach. 1992. Comparison of Black Friesian with Holstein $\times$ Black Friesian crossbreds for milk and beef production in Region X (Chile). Adv. Anim. Prod. 17:95-102.

Cienfuegos-Rivas, E. G., P. A. Oltenacu, R. W. Blake, S. J. Schwager, H. Castillo-Juarez, and F. J. Ruiz. 1999. Interaction between milk yield of Holstein cows in Mexico and the United States. J. Dairy Sci. 82:2218-2223.

Costa, C. N., R. W. Blake, E. J. Pollak, P. A. Oltenacu, R. L. Quaas, and S. R. Searle. 2000. Genetic analysis of Holstein cattle populations in Brazil and the United States. J. Dairy Sci. 83:2963-2974.

Dempster, A. P., N. M. Laird, and D. B. Rubin. 1977. Maximum likelihood from incomplete data via the EM algorithm. J. R. Stat. Soc. Ser. B 38:1-38. 
Dong, M. C., L. D. Van Vleck, and G. R. Wiggans. 1988. Effect of relationships on estimation of covariance components with an animal model and restricted maximum likelihood. J. Dairy Sci. 71:3047-3052.

Elzo, M. A. 1990a. Recursive procedures to compute the inverse of the multiple trait additive genetic covariance matrix in inbred and noninbred multibreed populations. J. Anim. Sci. 68:1215-1228.

Elzo, M. A. 1990b. Covariances among sire by breed group of dam interaction effects in multibreed sire evaluation procedures. J. Anim. Sci. 68:4079-4099.

Elzo, M. A. 1994. Restricted maximum likelihood procedures for estimation of additive and nonadditive genetic variances and covariances in multibreed populations. J. Anim. Sci. 72:3055-3065.

Elzo, M. A. 1996. Unconstrained procedures for the estimation of positive definite covariance matrices using restricted maximum likelihood in multibreed populations. J. Anim. Sci. 74:317-328.

Elzo, M. A., and D. L. Wakeman. 1998. Covariance components and predictions for additive and nonadditive preweaning growth genetic effects in an Angus-Brahman multibreed herd. J. Anim. Sci. 76:1290-1302.

Elzo, M. A., C. Manrique, G. Ossa, and O. Acosta. 1998a. Additive and nonadditive genetic variability for growth traits in the Turipaná Romosinuano-Zebu multibreed herd. J. Anim. Sci. 76:1539-1549.

Elzo, M. A., R. West, D. D. Johnson, and D. L. Wakeman. 1998b. Genetic variation and prediction of additive and nonadditive genetic effects for six carcass traits in an Angus-Brahman multibreed herd. J. Anim. Sci. 76:1810-1823.

Harville, D. A. 1977. Maximum likelihood approaches to variance component estimation and to related problems. J. Am. Stat. Assoc. 72:320-340.

Janss, L. L. G., and G. de Jong. 1999. MCMC based estimation of variance components in a very large dairy cattle data set. Pages
62-67 in Proc. Comput. Cattle Breeding Workshop, Tuusula, Finland. Online. Available: http://www-interbull.slu.se/bulletins/ framesida-pub.htm. Accessed July 18, 2003.

Koonawootrittriron, S., M. A. Elzo, and S. Tumwasorn. 2002. Estimation of multibreed genetic parameters and prediction of genetic values for first lactation 305-d milk yield, fat yield, and fat percentage in a Bos taurus $\times$ Bos indicus multibreed dairy population in Thailand. Thai J. Agric. Res. 35:339-360.

Moya, J. E., V. Esnaola, and R. Amunátegui. 1998. Seasonal report of the cattle sector: Preliminary results for 1998 and perspectives for 1999. Pages 1-17 in Agricultural Season No. 12. ODEPA, Ministry of Agriculture, Chile. Online. Available: http://www.odepa.gob.cl/servicios-informacion/tempo/t12-s2.pdf. Accessed October $23,2003$.

ODEPA. 2003. Dairy Bulletin-Year 2002. Ministry of Agriculture, Chile. Pages 1-51. Online. Available: http://www.odepa.gob.cl/ servicios-informacion/Lacteos/Leche- 2002.pdf. Accessed July $15,2003$.

Perez-Enciso, M., I. Misztal, and M. A. Elzo. 1994. FSPAK: An interface for public domain sparse matrix subroutines. Proc. 5th World Congr. Genet. Appl. Livest. Prod., Guelph, ON, Canada. 22:87-88.

Teuber, N. 1996. The prairie of the Central Plain in Region X (Valdivia-Chiloé). Pages 535-544 in Prairies for Chile. 2nd ed. INIA, Santiago, Chile.

Van Vleck, L. D., M. C. Dong, and G. R. Wiggans. 1988. Genetic (co)variances for milk and fat yields in California, New York, and Wisconsin for an animal model by restricted maximum likelihood. J. Dairy Sci. 71:3053-3060.

Weigel, K. A., R. Rekaya, N. R. Zwald, and W. F. Fikse. 2001. International genetic evaluation of dairy sires using a multiple-trait model with individual animal performance records. J. Dairy Sci. 84:2789-2795. 